\title{
PRE-SERVICE TEACHERS' CONCEPTIONS OF LITERARY EDUCATION - A CASE STUDY
}

\author{
Dulce Melão \\ School of Education of Viseu, CI\&DEl, Polytechnic Institute of Viseu (PORTUGAL)
}

\begin{abstract}
Few studies focus on pre-service teachers' conceptions of literary reading and how these might shape and influence their educational practices. Understanding such conceptions is relevant for i) the impact they may have on the training of readers; ii) the reassessment of pre-service teachers training; iii) the design of training programmes specifically tailored for their needs. Bearing that in mind, we present the findings from an empirical study concerning pre-service teachers' conceptions of literary reading and their implications for teaching practices in Primary Education.
\end{abstract}

We used a qualitative approach, within a multiple case study framework. The participants were 4 preservice teachers in their second year of a Master of Teaching (Early Childhood Education and Primary Education), enrolled in Supervised Teaching Practice (STP) in a Polytechnic Institute, in Portugal. The following Instruments were used to gather data: i) their lesson plans, during a nine-week period of training, focusing on the domain of Literary Education (as defined in the Programme and Curricular Goals of Portuguese in Basic Education); ii) a written report they produced at the end of their training.

A content analysis of the lesson plans and reports was performed, and categories were generated a priori and a posteriori concerning several dimensions: i) the importance these pre-service teachers attached to literary reading; ii) the aspects of literary reading they valued the most; iii) the texts they considered more adequate to fulfil their goals and iv) the reasons behind their choices.

As far as their lesson plans were concerned, we concluded that: i) most of these pre-service teachers considered literary reading relevant for increasing pupils' reading motivation, emphasizing the role of picturebooks as quality aesthetic objects to enhance children's imagination and creativity; ii) some of the important paratextual features of picturebooks were underestimated in their lesson plans and held a peripheral place in their conceptions of literary reading, mainly due to the relevance they gave to the acquisition of knowledge, rather than to reading for pleasure; iii) narratives were privileged, while few lesson plans contemplated poetry; iv) they mainly used print texts rather than texts displayed on screens; v) one of their main concerns was to achieve the goals established in the curricular document they had to follow.

The data collected from the written reports delivered at the end of their training revealed that: i) their own reading practices had an impact on their lesson plans, namely on the criteria used for choosing texts, mostly narrative ones; ii) they considered that literary education played a key role in fostering children's learning, enabling them to experience emotions that nurtured the development of social relationships and increased their enthusiasm for recreational reading; iii) they emphasized the importance of print texts for an affective literary reading experience.

Longitudinal studies, targeting pre-service teachers, may be relevant for a deeper understanding of their conceptions of literary reading and their potential consequences in future educational practices which might contribute to the training of readers. Research at an international level is needed in order to promote a wider debate about the role of literary education within the context of supervised teaching practices in Primary Education.

Keywords: Pre-service teachers; literary education; conceptions; reading.

\section{INTRODUCTION}

The importance of literary reading in Primary Education is widely recognized [1] [2] [3] and the relevance of the role played by pre-service teachers to foster reading engagement among children in primary schools has also been acknowledged [4] [5]. In Portugal, since 2012, several curriculum reforms have been under way in order to increase literary levels and promote reading engagement in Primary Education. Nevertheless, the Progress in International Reading Literacy Study (PIRLS) revealed that Portugal was one of the countries with lower average achievement [6] and the number of 
primary schools without a library or with scarce resources for reading promotion is higher than to European Union mean [7].

Some important steps have already been taken to increase literacy levels at school. The Programme and Curricular Goals of Portuguese [8], for example, has given greater impetus to Literary Education, highlighting the importance of working on a set of literary works that contribute to promote pupils' aesthetic sensibility, and create paths to rebuild global citizenship. Also, the recent curriculum document entitled Essential Learning Skills (2018) [9] states that: "In the field of literary education, students are expected to become familiar with and contact daily with reference literature, from which they can develop appreciation skills." [10]

However, despite the importance attached to Literary Education, little research has been carried out in Portugal in order to evaluate the results of the implemented classroom practices, in which teachers have an increased responsibility. In this sense, the training of future teachers also deserves attention. Thus, in the following sections of this paper, we present the findings from an empirical study concerning pre-service teachers' conceptions of literary reading and their implications for teaching practices in Primary Education.

\section{THEORETICAL FRAMEWORK}

The relevance of reading and reading literacy has long been the focus of attention in Portugal, as far as curriculum development is concerned. In 2012, The Programme and Curricular Goals of Portuguese for Basic Education was launched after a wider (and, at times, controversial) debate in the educational arena. The document is built around five domains - Speaking, Reading and Writing, Literary Education and Grammar. A list of mandatory texts was also created for each year so that special attention could be given to literary works (Portuguese and Foreign Literature).

One of the most outstanding initiatives promoted by the Ministry of Education was the creation and implementation of the National Programme for the Teaching of Portuguese (2006-2010), in Primary Education. Also worth noting is the development and consolidation of the National Reading Plan (2017-2027), mainly built around educational contexts but also including a set of activities aimed at the adult population (Adults Reading +, among others).

However, higher education students' have been left out of these initiatives, as they are mostly seen as proficient readers. Nonetheless, research on the reading practices of higher education students' point to several shortcomings, regarding their reading habits [11] [12] [13] [14] and their performance in reading comprehension [15] [16]. Some studies that focus on the reading practices of pre-service teachers [17] [18] corroborate the need to reflect attentively on these aspects, in view of pre-service teachers' contribution to motivate pupils' towards reading for recreational purposes.

Studies carried out on the conceptions of Literary Education of students attending a Bachelor degree course in Education ( $3^{\text {rd }}$ year) [19] and research focusing on the role of Literary Education in the Supervised Teaching Practice (STP) of future teachers', in Portugal [20] point to: i) its importance for fostering reading motivation; ii) students and pre-service teachers preference for narrative texts as a way to encourage pupils to improve their reading skills; iii) difficulties in implementing reading comprehension strategies that foster Literary Education.

Few international studies focus on future teachers' conceptions of literary education. In a study carried out by Munita (2013) [21], differences were found between "strong readers" and "weak readers", with regard to: i) their conceptions of reading (with the former considering literary reading embedded in the process of identity formation and the latter emphasizing the relevance of academic reading); ii) their reading experiences (only "strong readers" put into play their own affective relationship with literature and wanted to mirror it in children, and enabled them to build a similar relationship; while "weak readers" preferred reading for informational purposes). Contreras and Prats (2015) [22] studied the literary profile of four groups of future teachers (attending Barcelona University) and the importance they attached to literary education. Narrative texts stood out as a preference and reading for pleasure was rarely mentioned. As the authors of the study bluntly put it, "If you do not live, you do not feel literature, you can hardly take it to the classroom successfully" [23]. The same authors go on to propose several "digital paths" to enhance future teachers' reading habits and to increase reading motivation.

Theoretical studies on literary education have recently contributed to stressing the importance of the role played by reading for pleasure in educational settings, highlighting the need to review educational 
practices involving the study of literature in higher education, namely regarding future teachers' knowledge of literature [24] [25].

The recently updated position statement from the National Council of Teachers of English, entitled "Preparing teachers with knowledge of children's and young adult literature" (2018) [26], deserves a special mention here. Although not directly aimed at the Literary Education' goal fulfillment, it clearly states teacher education programs' responsibility to "build preservice teachers' capacity for continued growth, learning, and development as advocates of children's and young adult literature" and advocates the need to inspire them to become reading role-models, thus motivating readers.

Simpson's study on the use of children's literature in teaching [27] also deserves attention. The indepth research conducted in four different countries (Australia, Canada, the United Kingdom and the United States of America) provides a "contemporary critical review of the role of children's literature in pre-service teacher education" [28], highlighting the need for students to build up personal knowledge about literary texts and for institutions find stimulating thought-provoking paths for teacher training programs.

\section{METHODOLOGY}

The data collection and analysis were guided by the following research questions $(R Q)$ :

- RQ 1 How might lesson plans and written reports made by pre-service teachers, during their supervised teacher practice, shed some light on their conceptions of literary education?

- RQ2 How might such conceptions contribute to rethinking their training, encompassing the everchanging nature of literary education?

We opted for a qualitative approach, within a multiple case study framework. Such an approach puts the emphasis on the understanding that nothing is trivial and thus promotes the in-depth research of the object of study under investigation [29]. In addition, we consider it appropriate to use an inductive approach in data analysis, associated to qualitative research [30] [31], privileging an iterative process of searching for meanings emerging from the network of relationships that may contribute to the understanding of our object of study.

\subsection{Participants}

The participants in the study were four female pre-service teachers in their second year of a Master of Teaching (Early Childhood Education and Primary Education), enrolled in Supervised Teaching Practice (STP) in a Polytechnic Institute, in Portugal. They all had previously completed a first degree in Education in the same School of Education in Portugal and were Portuguese native speakers.

\subsection{Data collection tools}

The following Instruments were used to gather data: i) 36 lesson plans $\left(8^{*} 4\right.$ per pre-service teacher), during a nine-week period of training (in the third year of primary school), focusing on the domain of Literary Education (as defined in the Programme and Curricular Goals of Portuguese in Basic Education); ii) four written reports they produced at the end of their training.

\subsection{Research techniques}

Th content analysis was performed following Bardin [32] and Amado's [33] approach, encompassing an iterative process of coding to identify words/passages that captured practices, strategies and reflections. Such a process was carried out in order to allow us to infer the implicit meanings which echoed in the voices of these pre-service teachers.

\section{RESULTS AND DISCUSSION}

\subsection{Dimensions of literary education}

The content analysis results that emerged from pre-service teachers' lesson plans (LP-S), with regard to the dimensions of Literary Education are displayed in Table 1: 
Table 1 - Dimensions of Literary Education.

\begin{tabular}{|c|c|c|c|c|c|c|}
\hline Categories & Subcategories & $\begin{array}{c}\text { LP-S1 } \\
\text { (Freq.) }\end{array}$ & $\begin{array}{c}\text { LP-S2 } \\
\text { (Freq.) }\end{array}$ & $\begin{array}{c}\text { LP-S3 } \\
\text { (Freq.) }\end{array}$ & $\begin{array}{c}\text { LP-S4 } \\
\text { (Freq.) }\end{array}$ & Total \\
\hline development & $\begin{array}{c}\text { Imaginative } \\
\text { engagement with } \\
\text { literary texts }\end{array}$ & 5 & 4 & 3 & 3 & 15 \\
\cline { 2 - 7 } & $\begin{array}{c}\text { Reading motivation } \\
\text { enhancement }\end{array}$ & 2 & 2 & 1 & 1 & 6 \\
\hline \multirow{2}{*}{$\begin{array}{c}\text { Acquisition of } \\
\text { knowledge }\end{array}$} & $\begin{array}{c}\text { Knowledge of } \\
\text { Portuguese } \\
\text { Literature }\end{array}$ & 5 & 5 & 7 & 5 & 22 \\
\cline { 2 - 7 } & $\begin{array}{c}\text { Appreciation of } \\
\text { aspects of } \\
\text { Portuguese culture }\end{array}$ & 2 & 3 & 2 & 3 & 10 \\
\hline \multirow{2}{*}{$\begin{array}{c}\text { Appreciation of } \\
\text { picture books' } \\
\text { paratextual } \\
\text { features }\end{array}$} & $\begin{array}{c}\text { Engagement with } \\
\text { picturebooks' front } \\
\text { covers }\end{array}$ & 1 & 0 & 2 & 1 & 4 \\
\cline { 2 - 7 } & $\begin{array}{c}\text { Image/text } \\
\text { interaction }\end{array}$ & 1 & 1 & 1 & 1 & 4 \\
\hline
\end{tabular}

Table 1 shows that these pre-service teachers associated, above all, Literary Education with "Acquisition of knowledge", and highlighted the "Knowledge about Portuguese literature" in their lesson plans. This valuation seems to be very focused on a conception of Literary Education rooted, perhaps, along the pre-service teachers' school path. Their lesson plans thus seem to mirror such path. The "Appreciation of aspects of Portuguese culture" was related to an approach to narrative texts that focused on popular traditions, providing itineraries of discovery of oral and traditional literature. The pre-service teachers' lesson plans also included activities to develop reading comprehension, largely focusing on the identification of the main ideas of the selected texts, putting less emphasis on the teaching of inference skills.

"Creativity development" unfolded in "Imaginative engagement with literary texts" (which stood out) and "Reading motivation enhancement", to which future teachers attached less importance. Under the first subcategory, the lesson plans of these future teachers revealed that they implemented activities (such as giving a different ending to the story or retelling the narrative read in the first person as the main character of the story) that fostered pupils' creativity, stimulating their imagination and creating enriching reading experiences. "Reading motivation enhancement" was not as highlighted as expected. The lesson plans reflected the fact that future teachers did not consider it intrinsically related to Literary Education, appearing as a minor dimension, associated with reading motivation strategies such as reading out loud to others (LP-S1; LP-S4) or inviting guest readers to come to the classroom (LP-S2; LP-S3).

The category "Appreciation of picturebooks" was the least highlighted one, which deserves close attention, given the way in which such devaluation can be reflected in these pre-service teachers' future educational practices. Nowadays picturebooks are considered one of the most beautiful forms of interaction with literature, mainly as far as shared reading is concerned. The little emphasis given to its paratextual features may be due to: i) pre-service teachers' lack of knowledge about ways to explore picturebooks in the classroom; ii) their disregard for the important role played by paratextual features concerning reading engagement; iii) their difficulties in identifying picturebooks paratextual features (they only mentioned the front cover).

The analysis of pre-service teachers' lesson plans also revealed their preference for narrative texts. Poetry was only selected twice by each of the future teachers. Narrative texts were mainly selected for meeting the fulfillment of the targets outlined in the Programme and Curricular Goals of Portuguese (2015), regarding the development of reading comprehension and the knowledge of Portuguese literature and foreign literature. The choice of narrative texts for the implementation of reading activities in the classroom may be related to the students' enjoyment of this textual typology, as they may, perhaps, consider poetry more difficult. Their choices may also have been based on the ways they have been taught. 


\subsection{Importance of literary education}

The content analysis of the written reports (WR) that pre-service teachers delivered at the end of their training allowed us a more in-depth analysis of the dimensions focused on their lesson plans. The results of the analysis performed are presented in Table 2 :

Table 2 - Most valued aspects of literary education, according to pre-service teachers.

\begin{tabular}{|c|c|c|c|c|c|c|}
\hline Categories & Subcategories & $\begin{array}{l}\text { WRS1 } \\
\text { Freq. }\end{array}$ & $\begin{array}{l}\text { WRS2 } \\
\text { Freq. }\end{array}$ & $\begin{array}{l}\text { WRS3 } \\
\text { Freq. }\end{array}$ & $\begin{array}{l}\text { WRS4 } \\
\text { Freq. }\end{array}$ & Total \\
\hline \multirow[t]{3}{*}{$\begin{array}{l}\text { Contribution to an } \\
\text { affective reading } \\
\text { experience }\end{array}$} & $\begin{array}{l}\text { Role of picturebooks } \\
\text { as quality aesthetic } \\
\text { objects }\end{array}$ & 1 & 1 & 2 & 2 & 6 \\
\hline & $\begin{array}{l}\text { Importance of the } \\
\text { subjects addressed in } \\
\text { literary works }\end{array}$ & 1 & 2 & 2 & 2 & 7 \\
\hline & $\begin{array}{l}\text { Relevance of print } \\
\text { texts }\end{array}$ & 2 & 2 & 2 & 1 & 7 \\
\hline \multirow{2}{*}{$\begin{array}{l}\text { Improvement of } \\
\text { social skills }\end{array}$} & Emotional awareness & 3 & 1 & 1 & 2 & 7 \\
\hline & $\begin{array}{l}\text { Respect for cultural } \\
\text { diversity }\end{array}$ & 1 & 1 & 1 & 1 & 4 \\
\hline
\end{tabular}

The most valued aspect in Literary Education by the pre-service teachers was "Contribution to an affective reading experience". In their written reports, they stressed that: i) the few picturebooks used in the classroom aimed at encouraging literary reading had enabled shared reading practices that promoted bonds of affection among all; ii) the themes of the selected literary texts (such as friendship, fear, courage, freedom) also fostered a greater interaction in the classroom, stimulating an affective reading experience; iii) the presence of printed texts, and given pupils the opportunity to manipulate them and appreciate their illustrations, also provided a very pleasant reading experience.

The aspects mentioned by these pre-service teachers are corroborated by a growing body of literature, both with regard to picturebooks' contribution to an affective reading experience [34], and to the affective affordances of different materialities provided by the haptics of a physical book [35].

Within the category "Improvement of social skills", the sub-category "Respect for cultural diversity" was emphasized for its relevance to the development of global citizenship. The pre-service teachers acknowledged the importance of reading literary works such as Dancing in the Clouds [36] and Butterfly' Ears [37] for a better understanding of each other's differences, and of the beauty implied in caring and respecting one another, in a globalized world.

The sub-category "Emotional awareness" was related to the interaction of the pupils' in the classroom with the literary works selected, since shared reading allowed them to experience several emotions, thus nurturing the development of social relationships and increasing their enthusiasm for recreational 'reading. Pupils' discussion of what they read with peers has been related to high-order thinking, being envisaged as a powerful way to motivate readers [38].

\section{CONCLUSIONS}

This paper provided insight into pre-service-teachers' conceptions of literary education and how such conceptions were embedded in their lessons plans and in the written reports they delivered at the end of their training.

As far as their lesson plans were concerned, we concluded that: i) most of these pre-service teachers considered literary reading relevant for increasing pupils' reading motivation, emphasizing the role of picturebooks as quality aesthetic objects to enhance children's imagination and creativity; ii) some of the important paratextual features of picturebooks were underestimated in their lesson plans and held a peripheral place in their conceptions of literary reading, mainly due to the relevance they gave to the acquisition of knowledge, rather than to reading for pleasure; iii) narratives were privileged, and few lesson plans contemplated poetry; iv) they mainly used print texts rather than texts displayed on screens; v) one of their main concerns was to achieve the goals established in the curricular document they had to follow. 
The data collected from the written reports delivered at the end of their training revealed that: i) their own reading practices had an impact on their lesson plans, namely on the criteria used for choosing texts, mostly narrative ones; ii) they considered that literary education played a key role in fostering children's learning, enabling them to experience emotions that nurtured the development of social relationships and increased their enthusiasm for recreational reading; iii) they emphasized the importance of print texts for an affective literary reading experience.

Pre-service teachers' reader profile that emerged from the study points to several challenges: i) to carry out research projects that allow an in-depth investigation of pre-service teachers conceptions of literary education; ii) to rethink the design of their training, in order to increase their didactic performance concerning reading motivation; iii) to integrate nationwide pre-service teachers in the program already in place for the Portuguese National Reading Plan (PNRP), giving it its much deserved attention and relevance.

Longitudinal studies, targeting pre-service teachers, may be relevant for a deeper understanding of their conceptions of literary education and their potential consequences in future educational practices which might contribute to the training of readers. Research at an international level is also needed in order to promote a wider debate about the role of literary education within the context of supervised teaching practices in Primary Education.

\section{REFERENCES}

[1] F. Azevedo and Â. Balça (Coord.). Leitura e educação literária. Lisboa: PACTOR, 2016.

[2] Encabo-Fernández, E. and Jerez-Martínez, I. "Literatura infantil y educación primaria: análisis del valor formativo de los líbros más leídos en España," PERSPECTIVA, vol. 30, no. 3, pp. 947-966, 2012. Retrieved from https://periodicos.ufsc.br/index.php/perspectiva/article/viewFile/2175795X.2012v30n3p947/24393

[3] D. Waugh, S. Neaum and R. Waugh, Children's literature in primary schools, 2nd edition. London: SAGE, 2016.

[4] A. Simpson, The use of children's literature in teaching: a study of politics and professionalism within teacher education. London: Routledge, 2016.

[5] M. C. M. F. Arruda and K. N. Guimarães, "Formar professores para formar leitores: uma abordagem sobre o ensino da literatura," Anais do III CONEDU, Congresso Nacional de Educação. pp. 1-12, 2016. Campina Grande: Editora Realize. Retrieved from http://www.editorarealize.com.br/revistas/conedu/trabalhos/TRABALHO_EV056_MD1_SA4_ID52 64_15082016135320.pdf

[6] I. V. S. Mullis, M. O. Martin, P. Foy and M. Hooper, PIRLS 2016: international results in reading, 2017. Retrieved from https://files.eric.ed.gov/fulltext/ED580353.pdf

[7] A. Arqueiro, J. Cunha and M. L. Dionísio, Literacy in Portugal. Country report. Brussels: ELINET, 2016.

[8] H. Buescu, J. Morais, M. R. Rocha and V. M. Magalhães, Programa e metas curriculares de Português do ensino básico. Lisboa: Direção-Geral da Educação, 2015.

[9] Ministério da Educação, Aprendizagens essenciais. Ensino Básico - Português. Lisboa: Ministério da Educação, 2018.

[10] Ministério da Educação, Aprendizagens essenciais. Ensino Básico - Português. Lisboa: Ministério da Educação, 2018.

[11] R. S. G. Fernandes and R. F. Maia "Comportamento leitor de universitários: um estudo com alunos de administração e computação," Anais do SILEL, vol. 3, no.1, pp. 1-20, 2013. Retrieved from http://www.academia.edu/6694796/Comportamento_Leitor_de_Universit\%C3\%A1rios_Um_ Estudo_com_Alunos_de_Administra\%C3\%A7\%C3\%A3o_e_Computa\%C3\%A7\%C3\%A3o

[12] S. Yubero, E. Larrañaga and N. Pires, Estudo sobre os hábitos de leitura dos estudantes portugueses do ensino superior. Castelo Branco: Edições IPCB, 2014.

[13] H. St Clair-Thompson, A. Graham and S. Marsham, "Exploring the reading practices of undergraduate students," Education Inquiry, vol. 9, no. 3, pp. 284-298, 2018. DOI: $10.1080 / 20004508.2017 .1380487$ 
[14] S. Yubero and E. Larrañaga "Lectura y universidad: hábitos lectores de los estudiantes universitarios de España y Portugal," El profesional de la información, vol. 24, no. 6, pp. 717-723, 2015. Retrieved from https://recyt.fecyt.es//index.php/EPI/article/view/epi.2015.nov.03/23763

[15] K. L. Oliveira, "Considerações acerca da compreensão em leitura no ensino superior," Psicologia: Ciência e Profissão, vol. 31 no. 4, pp. 690-701, 2011. Retrieved from http://www.scielo.br/scielo.php?script=sci_arttext\&pid=\$141498932011000400003A.A.

[16] M. C. T. Vieira, "Os futuros professores e as estratégias de compreensão leitora," Revista Eletrônica Pesquiseduca, vol. 2, no. 4, pp. 209-229, 2010.

[17] C. Granado, "Teachers as readers: a study of the reading habits of future teachers/ El docente como lector: estudio de los hábitos lectores de futuros maestros," Cultura y Educación/Culture and Education, vol. 26, no.1, pp. 44-70, 2014.

[18] D. M. L. L. Saldanha and M. Amarilha,"'Literatura e formação do pedagogo: caminhos que (ainda) não se cruzam," Desenredo, vol. 12, no. 2, pp. 376-396, 2016. Retrieved from http://seer.upf.br/index.php/rd/article/view/6389/4055

[19] D. Melão, Educação literária e representações da leitura: itinerários de formação de professores. Revista de estudios e investigación en psicología y educación, vol. extr., 6, pp. 55-60, 2017. DOI: https://doi.org/10.17979/reipe.2017.0.06.2223. Retrieved from http://hdl.handle.net/10400.19/4755

[20] D. Melão and A. I., "«Por afetos e inquietações revisitadas»: práticas de leitura e processos de supervisão na formação inicial," in A Formação de Educador@s e Professor@s: Olhares a partir da UniverCidade de Évora, (A. Balça, C. Pomar, C. Costa, I. Bezelga, L. Moreira and O. Magalhães, eds.), pp. 135-160, Évora: Universidade de Évora, 2018.

[21] F. Munita, "Creencias y saberes de futuros maestros (lectores y no lectores) en torno a la educación literaria," Ocnos, no. 9, 69-87, 2013. Retrieved from http://www.revista.uclm. es/index.php/ocnos/article/view/227

[22] E. Contreras and M. Prats "¿La educación literaria de los futuros maestros es suficiente para ejercer de mediadores de las nuevas generaciones?," VIA ATLÂNTICA, no. 28, 29-44, 2015. Retrived from: http://www.periodicos.usp.br/viaatlantica/article/view/98568

[23] E. Contreras and M. Prats, "¿La educación literaria de los futuros maestros es suficiente para ejercer de mediadores de las nuevas generaciones?," VIA ATLÂNTICA, no. 28, 29-44, 2015. Retrived from: http://www.periodicos.usp.br/viaatlantica/article/view/98568

[24] J. D. Lorente, "La educación literaria. Revisión teórica y perspectivas de futuro," Didactica, Lengua y Literatura, vol. 25, pp. 135-156, 2013.

[25] J. C. Bernardes and R. A. Mateus, Literatura e ensino do Português. Lisboa: Fundação Francisco Manuel dos Santos, 2013.

[26] National Council of Teachers of English, Preparing teachers with knowledge of children's and young adult literature, 2018. Urbana, IL. Retrieved from http://www2.ncte.org/statement/chiladollitguideline/

[27] A. Simpson, The use of children's literature in teaching. London and New-York: Routledge, 2016.

[28] A. Simpson, The use of children's literature in teaching. London and New-York: Routledge, 2016.

[29] R. Bogdan, and S. Biklen, Investigação qualitativa em educação. Porto: Porto Editora, 1994.

[30] J. W. Creswell, Research design: qualitative, quantitative, and mixed methods approaches, 4th edition, 2014. London: Sage.

[31] C. P. Coutinho, Metodologia de investigação em ciências sociais e humanas: teoria e prática, 2011. Coimbra: Almedina.

[32] L. Bardin, Análise de conteúdo. Lisboa: Edições 70, 2004.

[33] J. Amado, "A técnica de análise de conteúdo," Referência, no. 5, pp. 53-63, 2000.

[34] M. Nikolajeva, "Picturebooks and emotional literacy," The reading teacher, vol. 47, no. 4, pp. 249254, 2013. Retrieved from http://nbrtlb.com/wp-content/uploads/2014/05/Picturebooks-andemotional-literacy.pdf 
[35] A. Mangen, "What hands may tell us about reading and writing," Educational Theory, vol. 66, no. 4, pp. 457-477, 2016.

[36] V. Starkoff, Dancing in the clouds. Matosinhos: Kalandraka, 2010.

[37] L. Aguilar, Butterfly ears. Matosinhos: Kalandraka, 2008.

[38] K. Tunks, R. Giles and S. Rogers, "A survey of teacher's selection and use of children's literature in elementary classrooms," The Language and Literacy Spectrum, vol. 25, pp. 58-71, 2015.

Retrieved from https://www.nysreading.org/system/files/ContentFiles/Volume\%2025.pdf 